\title{
COLOR RHYTHMS INSPIRED FROM THE HERITAGE ON THE ARCHITECTURAL SURFACES IN SIWA
}

Eman Ahmed RAMZI *

Mural Painting Department, Faculty of Fine Arts, Alexandria University, Egypt

\begin{abstract}
Siwa Oasis is one of the natural reserves in Egypt, and it is distinguished by the fact that it passed through different historical eras, including: the ancient Egyptian, the Greco-Roman, and the Islamic .. and it has multiple names such as: Nepta-The oasis of Amun, Jupiter, the Al-Aqsa Oasis, the Siwa Oasis, and the ruins of ancient heritage buildings are scattered, most of which were destroyed by the influence of the weather factors that the oasis was exposed to throughout the ages and different times, which led to erosion and damage to the archive blocks; It is a clay material consisting of sand and saline deposits used in the construction of these buildings. The oasis also suffers from random encroachment of modern buildings, which are not commensurate with their specificity, which has a negative impact on the natural and heritage environment. There are also some models of modern architecture that combine the architectural appearance of the old Siwa buildings with all their external and internal details, but they were built with modern foundations to ensure their survival for the longest possible period. That is, this ancient-looking architecture has a strong modern foundation to maintain a visual (hormonal) harmony between the old and the modern. In spite of this, the walls of these buildings are devoid of an aesthetic touch, so these surfaces were treated in a color rhythm inspired by the decorative units of the Siwa heritage while preserving the visual vision of the texture of these rough wall surfaces represented in the archive layer that covers the external architectural surface, without prejudice to the architectural pattern that Siwa Oasis is unique for it as one of the environmental heritage areas, so that the place does not lose its originality with the passage of time. Keywords Color Rhythms, Heritage, Architectural Surfaces, Siwa.
\end{abstract}

\section{Introduction}

It is considered the oasis of Siwa Siwa OasisOne of the natural reserves in Egypt, which is one of the depressions in the Western Desert, it is a green oasis, and the length of the Siwa depression is $82 \mathrm{~km}$, and its breadth ranges between: 9-28 km, and it is approximately $820 \mathrm{~km}$ from Cairo, about $65 \mathrm{~km}$ from the Libyan border, and $600 \mathrm{~km}$ from the west Nile Valley .Siwa Oasis has multiple names such as: Napata, CentariaSantariya, Which was found on hieroglyphic drawings and writings on the walls of the Temple of Amun in UghurmiAghrumi , As it is also called the oasis of jupiter amun It is said that the name Siwa came from the word "Sikh Umm."Sekht -Am ,Meaning the land of palm trees, and it was also called "the Oasis of Amun" until the era of the Ptolemies, and the Arabs knew it as "the Al-Aqsa Oasis," which is the name that was mentioned in the manuscripts of Al-Maqrizi

\section{Al-Maqrizi}

Sites of the Neolithic period were discovered in the oasis dating back to the period from 4000 to $3000 \mathrm{BC}$, and are distinguished by the fact that they passed through different historical eras, including: the ancient Egyptian, the Greco-Roman, and the Islamic Alexander the Great

\footnotetext{
* Corresponding author: artsadmin@alexu.edu.eg
} 
also visited the Temple of Amun in Siwa, and entered The Holy of Holies, which is a room that only the High Priest can enter, and the King and the architecture in Siwa have a special character in which it is unique ; Where materials derived from the surrounding environment were used in the construction of the old traditional mud houses, which are compatible with the ecosystem, so they used a material known in Arabic as the archive .kershefAnd in the Berber language of Siwa people known as Al-Ireej, and it is a clay material consisting of sandy and saline deposits that were extracted from the soil near salt lakes, or saltwater, so the soil in Siwa is rich in the clay that contains sand and salts. The walls are sometimes built from solid parts of the archive, with the use of archive mortar in the form of rows that are very similar to the foundations in traditional building systems, and this material is suitable for the environment; As it is characterized by the property of maintaining the temperature of the building in summer and winter, it soothes the temperature in summer with heating in the winter season.

\section{The Aim of the Research}

The ruins of ancient heritage buildings are scattered, most of which were destroyed by the influence of weather factors, which the oasis is exposed to throughout the ages and different times, which led to erosion and damage to the archive blocks .Only a few of these traditional old buildings remain.

The oasis also suffers from the random encroachment of modern buildings, which are not commensurate with their privacy, which has a negative impact that threatens the natural and heritage environment of Siwa Oasis.

While there are some models of modern architecture, which combines the architectural appearance of the old Siwa buildings with all their external and internal details, but they were built with modern foundations to ensure their survival for the longest possible period, as some treatments were added: such as white cement, and various rocks to extend the life of the mortar ; That is, this architecture, which looks old, has a strong foundation in order to achieve visual (hormonal ( harmony between the old and the modern.

This is evident in a large number of tourist resorts, such as: Siwa Shali Resort Resort Siwa Shali As well as some government facilities, such as: the Siwa House Museum .Siwa Center for Cultural and Natural Documentation -Siwa Friends Association - the administrative building of the Siwa Nature Reserve.

However, the walls of some of these facilities are devoid of an aesthetic touch, especially the Siwa Shali resort Siwa Shali Resort The research aims to deal with these surfaces in a color rhythm (weather-resistant colors), inspired by: the decorative units of the Siwi heritage, while preserving the visual vision of the texture of these rough wall surfaces represented in the 
archive layer that covers the architectural surface, and without prejudice to the architectural pattern that is unique It includes Siwa Oasis as one of the environmental heritage areas, so that the place does not lose its originality with the passage of time.

\section{Action Steps}

Siwa Shali Resort was chosen Siwa Shali Resort As a model of modern architecture, which combines the architectural appearance of the old Siwa buildings with all its external and internal details, but it was built with modern foundations of red or white bricks to ensure its survival as long as possible, and the resort consists of a number of independent chalets, each chalet is built in the style of old Siwa houses.

Various live scenes and footage of the different architectural surfaces were filmed before they were wall-treated, whether in the external architecture of the walls and facades of the chalets, or the interior architecture of fixed furniture, as well as some construction units from cafeterias, and sessions in the resort - images were collected from the Siwi heritage represented in: decorative units From baskets, wicker dishes, kilims, embroidery of clothes, metalwork, and jewelry

It includes traditional craftsmanship, legacy, and heritage ; Where the creative renewal that combines: the spontaneous, innate, authentic and symbolic formulated through inherited perceptions, reflecting the culture of the society.

-Using a program Adobe Photoshop CS5As a tool for design preparation - . The designs of the decorative units of the Siwa heritage have been prepared in accordance with the organic external shape of the roofs, and the openings they contain, as well as taking into account the use of colors in proportion to the color of the wall, taking into account the preservation of some areas of the original color of the wall whenever the design requires it, In order to achieve the color harmony, unity, and coherence between all the elements in the design, to finally be a rhythm of color that carries with it the ancient Siwa heritage.

\section{Conclusion}

With the application of this research, Siwa will turn into a large tourist resort, and there must be a methodology in preserving the ancient heritage of Siwa, in addition to restoring the remains of ancient buildings that are about to disappear, and converting them into museums or tourist attractions, it is also possible to rebuild and reconstruct the areas. The deteriorating urban environment in Siwa, which requires replacement and renewal on a large scale, while preserving the architectural character of the historical Siwa Oasis as a historical symbol and a civilized heritage, to achieve an integrated visual vision based on visual harmony (hormonal) between the old and the modern, that is, harmony between modernity and originality. 
Consciously .Modern buildings made of red bricks can be renovated by adding the traditional original materials used in construction from the outside, such as cushions mortar, so that the place does not lose its originality, with the possibility of increasing the ability of the original materials used in the building to adhere to the cohesion, using types of strong adhesives by following the method of reinforcement ConsolidationWith the addition of color touches inspired by the ancient Siwa heritage.

\section{Recommendations}

1. Preserving the components of Siwa Oasis and its natural environmental characteristics, as well as preserving the intersecting organic urban fabric, because it is related to the human scale of the people of the oasis - strengthening the protection of the cultural and civilizational heritage, and societal awareness of the importance of consolidating the cultural heritage, and the original cultural values of the oasis community.

2. Establishing special legislations to preserve the endangered cultural heritage.

3. The structural restoration of the old deteriorating traditional buildings, and the restoration is done by experts and according to accurate specialized studies.

4. Preparing planning projects to protect and develop ancient heritage areas with a private ecosystem.

5. Paying attention to integrated, environmentally sustainable tourism development in all its components and vocabulary.

6. Funding projects for the rehabilitation and development of heritage and historical areas as a national wealth, so as not to obliterate their identity.

\section{References}

1. Arnold Hauser, translated by Fouad Zakaria .Art and Society Throughout History, Part Two, The Egyptian General Book Authority, 2015.

2. Hassan Mahmoud Yousry, Bari Bahaa El Din Hafez, Bahaa El Din Mohamed and others .The guidebook, foundations and standards for cultural coordination for heritage buildings of distinct and valuable regions, first edition, first edition 2010.

3. Rashid Ghamry .Sahar Al-Wahat, The Egyptian General Book Authority, 2016.

4. Sami Bakhit .Decorations of Egyptian Folk Crafts between Heritage and Contemporary, The Egyptian General Book Authority, 2013.

5. Izzat Qarni .The Origins of Art, The Egyptian General Book Authority, 2016 .Cassandra Vivian .The Western Desert of Egypt, a brief guide for the explorer, translated by Muhammad Sabry Mahsoub, National Center for Translation, Cairo, 2015.

6. Mohsen Mohamed Attia .Discovering Beauty in Art and Nature, The Egyptian Book 
House, 2005 AD.

7. Mohammed Amin Abdel Samad .Oasis of Art and Beauty, The Egyptian General Book Authority, 2012.

8. Llaria Bilancetti, Searching for Siwan Embroidery, Published Via Siwan \& Tangier, 2012 .

9. Margaret M. Vale, Siwa jewelry, Costume, and life in an Egyptian Oasis, American University, Cairo Press, 2015.

10. Reem Assem Saleh, Siwa Oasis studios as acase study, Proceedings of the International Conference on Cities' Identity Through Architecture \& Arts, 2017.

11. Hala S. Mahdi, Cultural Heritage and its Role in Enriching Egyptian Architecture, International Journal of Architectural Engineering and Urban Research, Vol. 1, No. 1, 2018, pp. 20-25.

12. Sahar M. Dargham, Alexandrian Heritage and its Creative Role in Producing Contemporary Artworks For Fine Art Students, International Journal Of Architectural Engineering and Urban Research, Vol. 1, No. 1, 2018, pp. 1-3.

Received: January 25, 2018

Accepted: March 30, 2018 